Compositional changes in lime-based mortars exposed to different environments

J. Lanas ${ }^{a}$, R. Sirera ${ }^{\text {, }}$ J.I. Alvarez ${ }^{\text {b, } *}$

${ }^{a}$ Laboratorio de Edificación, Universidad de Navarra, 31080 Pamplona, Spain

${ }^{\mathrm{b}}$ Departamento de Química, Universidad de Navarra, 31080 Pamplona, Spain

$\mathbf{N}^{\circ}$ of pages: 19

$\mathbf{N}^{0}$ of tables: 6

$\mathbf{N}^{\circ}$ of figures: 9

Keywords: $\mathrm{SO}_{2}$-chamber, Climatic ageing, Gypsum, Syngenite, TG-DTA

Please, send all correspondence to:

Dr. José I. Alvarez Galindo

Dpto. de Química

Fac. de Ciencias

Universidad de Navarra

$\mathrm{C} /$ Irunlarrea $\mathrm{s} / \mathrm{n}$

31.080 Pamplona (Navarra)

Spain

Phone: 34948425600

Fax: 34948425649

E-mail: jalvarez@unav.es 


\title{
Compositional changes in lime-based mortars exposed to different environments
}

\author{
J. Lanas ${ }^{a}$, R. Sirera ${ }^{b}$, J.I. Alvarez ${ }^{b, *}$ \\ a Laboratorio de Edificación, Universidad de Navarra, 31080 Pamplona, Spain \\ b Departamento de Química, Universidad de Navarra, 31080 Pamplona, Spain
}

\begin{abstract}
Specimens of aerial and hydraulic lime-based mortars to be used in restoration works were prepared, hardened and subjected to different environments to study their compositional changes during setting, hardening and exposure to environment. Outside exposure, weathering cycles in a climatic chamber, $\mathrm{SO}_{2}$-rich environment and indoor exposure (as control group) were selected to expose the mortars. XRD, FTIR and TG-DTA analyses were performed at 7, 14, 21 and 28 days to determine the chemical and mineralogical composition, as well as the formation of the degradation products. Outside and $\mathrm{SO}_{2}$-chamber exposures and increasing the relative humidity allowed faster carbonation (enhancing $\mathrm{CO}_{2}(\mathrm{~g})$ dissolution) and hydration of hydraulic compounds. In $\mathrm{SO}_{2}$-chamber, sulfate attack appears as a surface phenomenon, giving: gypsum in aerial specimens and gypsum and syngenite in hydraulic specimens.
\end{abstract}

Keywords: $\mathrm{SO}_{2}$-chamber, Climatic ageing, Gypsum, Syngenite, TG-DTA 


\section{Introduction}

The use of lime mortars in restoration of historical buildings has been described in several previous works [1]. In this research, the mechanical behavior of aerial lime and hydraulic limebased mortars has been studied [2,3]. The durability of these mortars is a critical aspect that has been considered by exposing mortar samples to different environmental conditions: outside exposure (urban atmosphere) [4], $\mathrm{SO}_{2}$ pollutant exposure [5-8], weathering cycles (in a climatic chamber) [9-10] or freeze-thaw cycles [11,12].

Environmental conditions affect the composition of the mortars. For example, a relative humidity has an influence on the $\mathrm{Ca}(\mathrm{OH})_{2}$ carbonation and on the stability degree of calcium silicate hydrated (C-S-H) in hydraulic binders. The occurrence of $\mathrm{SO}_{2}$ allows formation of new products, i.e. the sulfate attack phenomenon [4]. The compositional changes and the new products formed have an influence on the microstructure and the mechanical properties of the repair mortars, as well as on their durability. As an example, in hydraulic binders, ettringite, a calcium sulfoaluminate, can be formed as a result of the reaction between the calcium aluminates of the mortar and the gypsum produced by the sulfate attack process (Eq. 1) [13]:

$$
3\left(\mathrm{CaSO}_{4} \cdot 2 \mathrm{H}_{2} \mathrm{O}\right)+3 \mathrm{CaO} \cdot \mathrm{Al}_{2} \mathrm{O}_{3} \cdot 6 \mathrm{H}_{2} \mathrm{O}+20 \mathrm{H}_{2} \mathrm{O} \rightarrow 3 \mathrm{CaO} \cdot \mathrm{Al}_{2} \mathrm{O}_{3} \cdot 3 \mathrm{CaSO}_{4} \cdot 32 \mathrm{H}_{2} \mathrm{O}(1)
$$

Formation of ettringite, a strongly hydrated, non-water-soluble salt, after hardening of the mortar, gives rise to cracks and fractures due to the expansive nature of the reaction [14].

The aim of this paper is to study the variation of the mineralogical and chemical composition in hardened repair lime-based mortars (aerial and hydraulic) after different exposure tests: outside exposure, weathering cycles (in a climatic chamber), $\mathrm{SO}_{2}$-rich environment (in an $\mathrm{SO}_{2}$ chamber) and indoor exposure (laboratory conditions). XRD, FTIR and TG-DTA were used for this purpose.

\section{Experimental work}

\subsection{Mortars}


Two different kinds of limes have been used to prepare the mortars: aerial lime and natural hydraulic lime. The first one is a commercial-hydrated lime powder of the class CL90 according to the European norm [15] and was supplied by Calinsa S.A. (Navarra). The second one is a commercial lime of the class HL5 [15], and provided by Chaux Bruyeres (Saint-Front-surLémance, Fumel). Table 1 gives the chemical characterization (according to European Standard) [16] and Fig. 1 shows their X-ray diffractograms.

Table 1. Chemical analysis of the aerial, natural hydraulic lime and aggregate $\mathrm{e}^{\mathrm{a}, \mathrm{b}}$.

\begin{tabular}{|c|c|c|c|c|c|c|c|c|}
\hline $\begin{array}{c}\text { Raw } \\
\text { material }\end{array}$ & $\begin{array}{l}\text { I. L. } \\
(\%)\end{array}$ & $\begin{array}{l}\mathrm{SiO}_{2} \\
(\%)\end{array}$ & $\begin{array}{l}\mathrm{CaO} \\
(\%)\end{array}$ & $\begin{array}{c}\text { MgO } \\
(\%)\end{array}$ & $\begin{array}{c}\mathbf{R}_{2} \mathbf{O}_{3}{ }^{d} \\
(\%)\end{array}$ & $\begin{array}{l}\mathrm{SO}_{3} \\
(\%)\end{array}$ & $\begin{array}{c}\mathrm{Na}_{2} \mathrm{O} \\
(\%)\end{array}$ & $\begin{array}{l}\mathrm{K}_{2} \mathrm{O} \\
(\%)\end{array}$ \\
\hline $\begin{array}{l}\text { Aerial lime } \\
\text { (Estavol }())\end{array}$ & 25.46 & 0.71 & 68.26 & 3.55 & 0.55 & 0.96 & 0.07 & 0.04 \\
\hline $\begin{array}{l}\text { Natural } \\
\text { hydraulic } \\
\text { lime } \\
\end{array}$ & 15.00 & 12.57 & 54.26 & 7.65 & 6.58 & 2.13 & 0.34 & 1.35 \\
\hline $\begin{array}{l}\text { Aggregate } \\
\text { (Ag) }\end{array}$ & 43.10 & 0.49 & 52.83 & 2.28 & 1.14 & 0.57 & 0.07 & 0.05 \\
\hline
\end{tabular}

A pure limestone sand of angular edges with controlled granulometry supplied by CTH Navarra (Navarra) was used as aggregate. Its chemical composition, X-ray diffractogram and particle size distribution are given in Table 1, Fig.1 and Fig. 2, respectively.

The binder:aggregate ratio (B/Ag) prepared was 1:1 by volume due to the best mechanical behavior of this proportion, in both kinds of lime [2,3]. Volume proportions of compounds were converted to weight to avoid measurement imprecision on. Table 2 summarizes the equivalencies.

The water:lime (W:L) ratio used to prepare all mortar pastes was 1:2. A normal consistency and a good workability (165 mm and $170 \mathrm{~mm}$ for aerial and hydraulic lime mortars, respectively, measured by the flow table test [17]) were achieved by using this water amount. The mixer used was a Proeti ETI 26.0072 [18]. Water and lime were blended for 5 min. Aggregate was then added and mixed for 5 min at low speed, and finally for 1 min at high speed. 


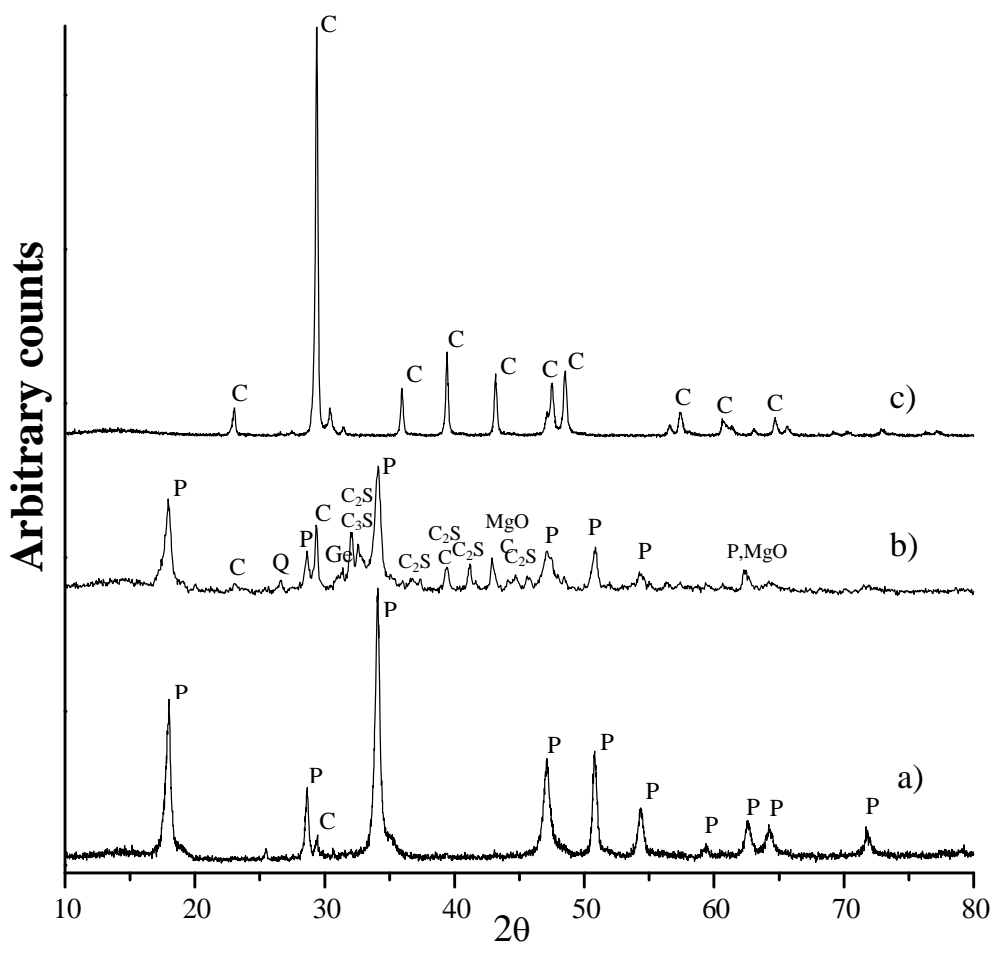

Fig. 1. XRD of: a) aerial lime; b) natural hydraulic lime; c) aggregate (C: Calcite (ICDD 05-0586); P: Portlandite, $\mathrm{Ca}(\mathrm{OH})_{2}$ (ICDD 44-1481); $\mathrm{C}_{2} \mathrm{~S}$ : Dicalcium silicate, $2 \mathrm{CaO} \mathrm{SiO}_{2}$ (ICDD 02-0843); $\mathrm{C}_{3} \mathrm{~S}$ : Tricalcium silicate, $3 \mathrm{CaO}^{-\mathrm{SiO}_{2}}$ (ICDD 02-0849); MgO: Periclase (ICDD 45-0946); Ge: Gehlenite, $\mathrm{C}_{2} \mathrm{AS}, \mathrm{Ca}_{2} \mathrm{Al}_{2} \mathrm{SiO}_{7}$ (ICDD 35-0755); Q: Ouartz (ICDD 46-1045)).

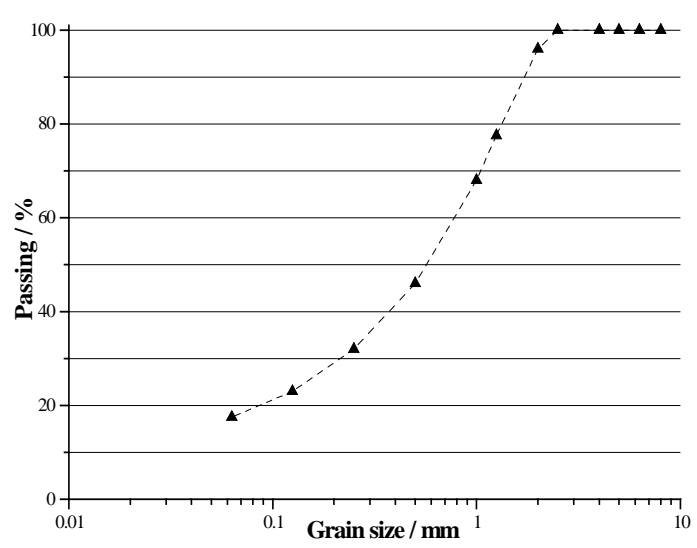

Fig. 2. Grain size distribution of the aggregate.

Table 2. Equivalent volume proportion/weight proportion for aerial and hydraulic lime-based mortars.

\begin{tabular}{lccccc}
\hline $\begin{array}{c}\text { Lime-based } \\
\text { mortar }\end{array}$ & $\begin{array}{c}\text { Volume } \\
\text { proportion }\end{array}$ & Material & $\begin{array}{c}\text { Volume } \\
\text { (L) }\end{array}$ & $\begin{array}{c}\text { Weight } \\
\text { (g) }\end{array}$ & $\begin{array}{c}\text { Weight } \\
\text { proportion }\end{array}$ \\
\hline \multirow{2}{*}{ Aerial } & $1: 1$ & $\begin{array}{c}\text { Lime } \\
\text { Aggregate }\end{array}$ & 2.00 & 800 & \\
Hydraulic & $1: 1$ & Lime & 2.00 & 3000 & $1: 3.75$ \\
& & Aggregate & 2.00 & 3000 & $1: 2.14$ \\
\hline
\end{tabular}


The mortars were molded in prismatic 40x40x160 mm casts [19] using an ICON automatic jolting table to compact them and remove any air bubbles and voids [18]. They remained in the molds in ambient laboratory conditions (RH $60 \pm 10 \%$ and $20 \pm 5^{\circ} \mathrm{C}$ ) for 4 days. After this period, the samples were demolded, weighed and cured for 24 more days in the same laboratory conditions. Therefore, prepared mortars were hardened 28 days before performing the different tests.

\subsection{Environments of exposure}

After 28 days, samples were placed in: (i) outside exposure; (ii) in a climatic chamber CCI FCH-XENOLAB 1500: climatic cycles of 24 hours with different conditions of relative humidity (RH), temperature (T), ultraviolet light and rain. Table 3 summarizes the steps of the climatic cycles; (iii) in an $\mathrm{SO}_{2}$ chamber [20,21] with cycles of 24 hours according to SFW 2,0S DIN 50018 [21] (Table 4); (iv) in ambient laboratory conditions (RH $60 \pm 10 \%$ and $20 \pm 5^{\circ} \mathrm{C}$ ), as a control group.

Table 3. Steps of the climatic chamber.

\begin{tabular}{cccccc}
\hline $\begin{array}{c}\text { Cycle } \\
(\mathbf{2 4} \mathbf{~ h})\end{array}$ & $\begin{array}{c}\text { Temperature } \\
\left({ }^{\mathbf{0}} \mathbf{C}\right)\end{array}$ & $\begin{array}{c}\mathbf{R . ~ H}^{\mathbf{a}} \\
\mathbf{( \% )}\end{array}$ & Rain & Light & $\begin{array}{c}\text { Time } \\
(\mathbf{m i n})\end{array}$ \\
\hline Step 1 & 35 & 30 & no & yes & 160 \\
Step 2 & 12 & 60 & yes & no & 160 \\
Step 3 & -5 & 0 & no & no & 160 \\
Step 4 & 12 & 60 & no & no & 160 \\
Step 5 & 35 & 30 & no & yes & 160 \\
Step 6 & 12 & 80 & yes & no & 160 \\
Step 7 & 35 & 30 & no & yes & 160 \\
Step 8 & -5 & 0 & no & no & 160 \\
Step 9 & 12 & 60 & no & no & 160 \\
\hline
\end{tabular}

${ }^{a}$ Relative humidity

Table 4. $\mathrm{SO}_{2}$-chamber cycles.

\begin{tabular}{ccccccc}
\hline $\begin{array}{c}\text { Cycle } \\
\text { duration }\end{array}$ & $\begin{array}{c}\mathrm{SO}_{2} \\
\text { addition } \\
\text { (L) }\end{array}$ & $\begin{array}{c}\mathbf{H}_{2} \mathbf{O} \\
\text { addition } \\
\text { (L) }\end{array}$ & Steps & $\begin{array}{c}\text { T } \\
\left({ }^{\circ} \mathbf{C}\right)\end{array}$ & $\begin{array}{c}\text { R. H. } \\
\text { (\%) }\end{array}$ & $\begin{array}{c}\text { Time } \\
\text { (h) }\end{array}$ \\
\hline & & & & & \\
\hline \multirow{2}{*}{$24 \mathrm{~h}$} & 2 & $2 \pm 0.2$ & step 1 & $40 \pm 3$ & 100 & 8 \\
& & step 2 & $\begin{array}{c}\text { Room } \\
\text { temperature }\end{array}$ & $<75$ & 16 \\
\hline
\end{tabular}


105 specimens were prepared for each mortar type, i.e. a total of 210 specimens have been studied altogether. Tests and analyses were performed after exposure times of 7, 14, 21 and 28 days. The reported results are an average for three similar specimens. For analyses, a significant portion of each specimen was ground in an agate mortar. Samples were taken from the core and the edges of the mortar specimens to avoid differences in the carbonation depth (analyses of the bulk sample). In some cases, measurements of the surface of the samples were carried out.

The mineralogical phases contained in the samples were determined by means of X-ray diffraction (XRD) using a Bruker D8 Advance diffractometer (Karlsruhe, Germany) with a CuK $\alpha 1$ radiation and $0.02^{\circ} 2 \theta$ increment and $1 \mathrm{~s} \cdot \operatorname{step}^{-1}$, scanning from 2 to $90^{\circ} 2 \theta$. The results were compared with the ICDD database.

Powdered samples were analyzed by FT-IR spectroscopy, in KBr pellets with a NicoletFTIR Avatar 360, with OMNIC E.S.P. software. The resolution was $2 \mathrm{~cm}^{-1}$ and the spectra were the result of averaging 100 scans. All measurements were carried out at $20 \pm 1^{\circ} \mathrm{C}$ and ca. $40 \%$ RH.

Differential thermal and thermogravimetric analyses (DTA-TG) were carried out with a simultaneous TGA-sDTA 851 Mettler Toledo thermoanalyser (Schwerzenbach, Switzerland) using alumina crucibles, with holed lids, at $20^{\circ} \mathrm{C} \min ^{-1}$ heating rate, under static air atmosphere, from ambient temperature to $1200^{\circ} \mathrm{C}$.

\section{Results}

\subsection{Weight change}

The weight changes of the samples are given in Figs. 3 and 4. In Table 5, the humidity degree of the specimens is collected. A lower value for indoor exposure than for outside exposure can be seen. 


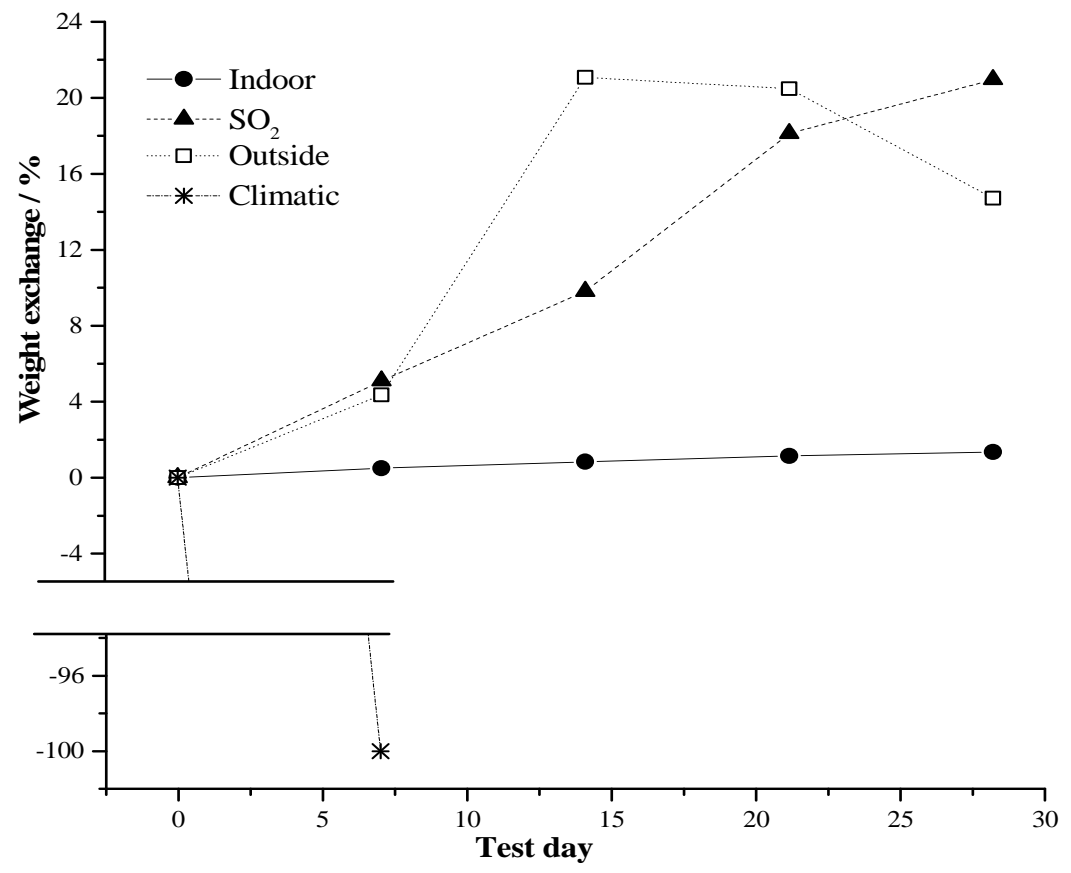

Fig. 3. Weight vs. test time in aerial lime based mortars exposed at different conditions.

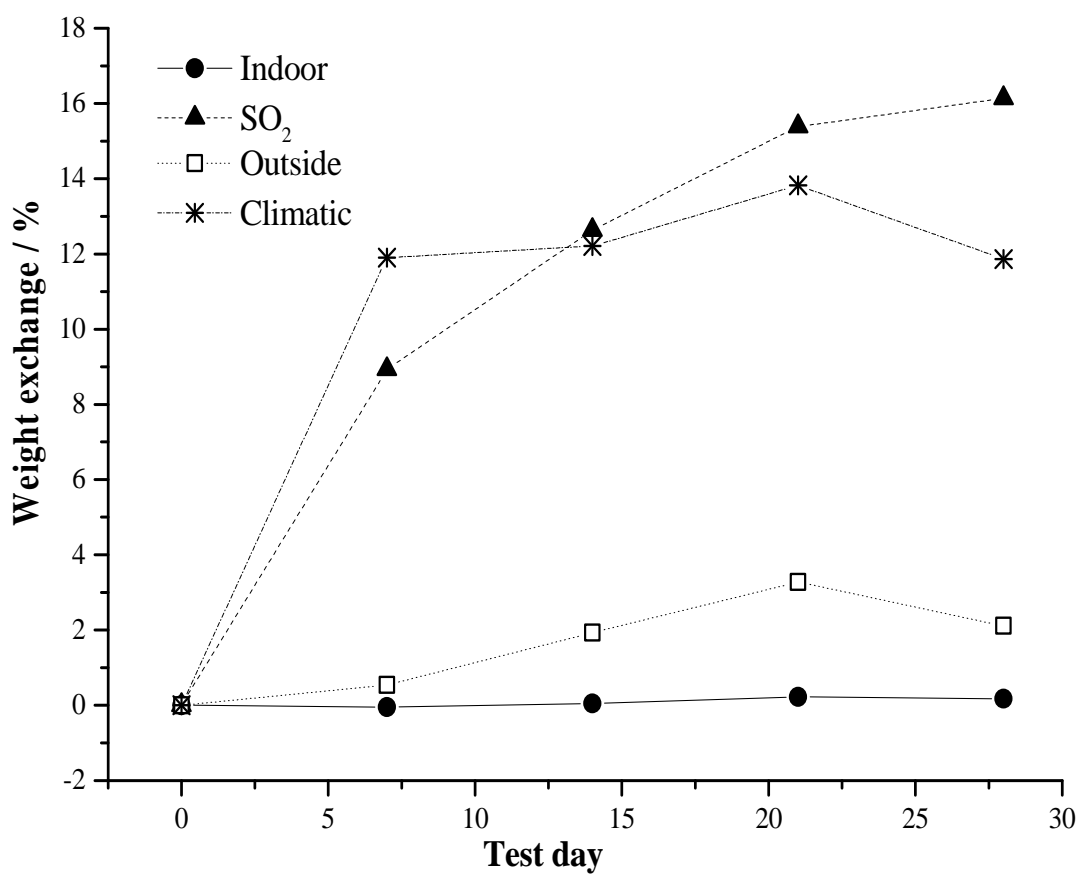

Fig. 4. Weight vs. test time in hydraulic lime based mortars exposed at different conditions. 
Table 5. Humidity degree of the specimens exposed, expressed as free water content (\%).

\begin{tabular}{|c|c|c|c|c|c|c|c|c|}
\hline \multirow[b]{3}{*}{$\begin{array}{l}\text { Test } \\
\text { day }\end{array}$} & \multicolumn{8}{|c|}{$\%$ water } \\
\hline & \multicolumn{4}{|c|}{ Aerial lime-based mortars } & \multicolumn{4}{|c|}{ Hydraulic lime-based mortars } \\
\hline & Outside & Climatic & Indoor & $\mathrm{SO}_{2}$ & Outside & Climatic & Indoor & $\mathrm{SO}_{2}$ \\
\hline 0 & \multicolumn{4}{|c|}{$\leftarrow 0.35 \rightarrow$} & \multicolumn{4}{|c|}{$\leftarrow 1.58 \rightarrow$} \\
\hline 7 & 7.54 & - & 0.21 & 5.48 & 1.96 & 11.88 & 1.78 & 11.40 \\
\hline 14 & 13.66 & - & 0.16 & 6.12 & 2.74 & 12.69 & 1.80 & 13.77 \\
\hline 21 & 15.47 & - & 0.17 & 12.71 & 3.54 & 13.64 & 1.52 & 13.82 \\
\hline 28 & 12.35 & - & 0.54 & 11.11 & 2.00 & 12.80 & 1.38 & 13.77 \\
\hline
\end{tabular}

\subsection{XRD analyses}

Fig. 5 shows the XRD patters from: a) the bulk of the sample of the specimens, and from b) the external layer. In aerial lime-based mortars, calcite, portlandite and quartz have been found in the different environments. Also gypsum $\left(\mathrm{CaSO}_{4} \cdot 2 \mathrm{H}_{2} \mathrm{O}\right)$ appears in the external layer after $\mathrm{SO}_{2}$-rich environment exposure, as expected.

In hydraulic lime-based mortars, also calcite, portlandite and quartz can be detected. C-S-H is not clearly detected by XRD since it could stay in amorphous form. Main XRD peaks of diffraction of gehlenite and calcium silicates $\left(\mathrm{C}_{2} \mathrm{~S}\right.$ and $\left.\mathrm{C}_{3} \mathrm{~S}\right)$ could be recognized, however the background, the very close peaks and the small amount of these compounds hinder a welldefined identification [3].

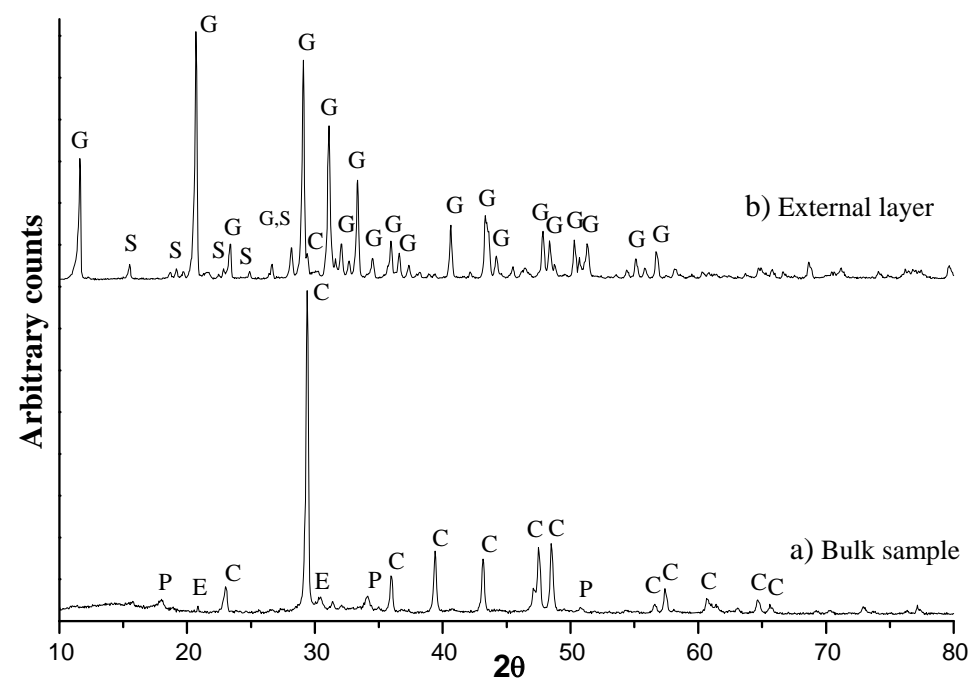

Fig. 5. XRD of: a) the bulk of the sample; and b) external layer. Hydraulic lime mortar in $\mathrm{SO}_{2}$-chamber exposure. (C: Calcite (ICDD 05-0586); P: Portlandite (ICDD 44-1481); E: Ettringite (ICDD 41-1451); G: Gypsum (ICDD 33-0311); S: Syngenite (ICDD 28-0739)). 
In $\mathrm{SO}_{2}$-chamber exposure, gypsum and syngenite $\left(\mathrm{K}_{2} \mathrm{Ca}\left(\mathrm{SO}_{4}\right)_{2} \cdot 2 \mathrm{H}_{2} \mathrm{O}\right)$ [7] have been detected in the external layer as a result of the sulfate attack process. Therefore, this process takes place in a superficial way. Traces of ettringite (described as an alteration product after $\mathrm{SO}_{2}$-exposure in hydraulic binders) [22] appear in the XRD pattern of the bulk of the sample.

From XRD patterns, a semiquantitative $\mathrm{CaCO}_{3}(\%) / \mathrm{Ca}(\mathrm{OH})_{2}(\%)$ relation can be obtained to compare the carbonation of the mortars through the intensity of the diffraction peaks (taking into account the peaks at $d=3.03 \AA$ and $d=2.628 \AA$, for $\mathrm{CaCO}_{3}$ and $\mathrm{Ca}(\mathrm{OH})_{2}$, respectively). Table 6 summarizes the mean results as a function of the exposure day.

Table 6. Ratio of $\mathrm{CaCO}_{3} / \mathrm{Ca}(\mathrm{OH})_{2}$ from XRD measurements expressed as percentages of calcite/portlandite in different exposures.

\begin{tabular}{|c|c|c|c|c|c|c|c|c|}
\hline \multirow[b]{3}{*}{$\begin{array}{l}\text { Test } \\
\text { day }\end{array}$} & \multicolumn{8}{|c|}{$\% \mathrm{CaCO}_{3} / \% \mathrm{Ca}(\mathrm{OH})_{2}$} \\
\hline & \multicolumn{4}{|c|}{ Aerial lime-based mortars } & \multicolumn{4}{|c|}{ Hydraulic lime-based mortars } \\
\hline & Outside & Climatic & Indoor & $\mathrm{SO}_{2}$ & Outside & Climatic & Indoor & $\mathrm{SO}_{2}$ \\
\hline 0 & \multicolumn{4}{|c|}{$\leftarrow 3.9 \rightarrow$} & \multicolumn{4}{|c|}{$\leftarrow 13.5 \rightarrow$} \\
\hline 7 & 5.9 & 8.0 & 5.4 & 5.8 & 13.6 & 17.5 & 13.9 & 17.9 \\
\hline 14 & 5.9 & - & 6.2 & 5.9 & 19.0 & 17.5 & 14.4 & 19.4 \\
\hline 21 & 7.0 & - & 7.8 & 9.6 & 15.1 & 14.1 & 16.6 & 18.6 \\
\hline 28 & 10.4 & - & 9.6 & 13.9 & 15.4 & 17.9 & 14.9 & 19.0 \\
\hline
\end{tabular}

\subsection{FTIR analyses}

Analyses of the surface and of the bulk of the samples were carried out by FTIR.

In aerial mortars subjected to outside, indoor and climatic chamber exposures, absorption bands at $\sim 1420 \mathrm{~cm}^{-1}$ (broad bands), 874 and $714 \mathrm{~cm}^{-1}$ (strong peaks) are indicative for the presence of calcite [7]. The sharp vibrational band at $\sim 3640 \mathrm{~cm}^{-1}$ corresponds to $\mathrm{OH}$ stretching, and it is designed to the calcium hydroxide (Fig. 6(a) shows, as an example, FTIR spectrum of an aerial specimen after 28 test days in indoor exposure).

In $\mathrm{SO}_{2}$-chamber exposure, FTIR spectrum (Fig. 6(b)) shows other bands at $~ 3548,3410$, $1624,1143,1117,1017,713,670$ and $603 \mathrm{~cm}^{-1}$, indicating the presence of gypsum. Also it can be observed bands corresponding to calcite and portlandite. Vibrational bands at 990 and 947 $\mathrm{cm}^{-1}$ arise from $\mathrm{SO}_{3}{ }^{2-}$ vibrations. 


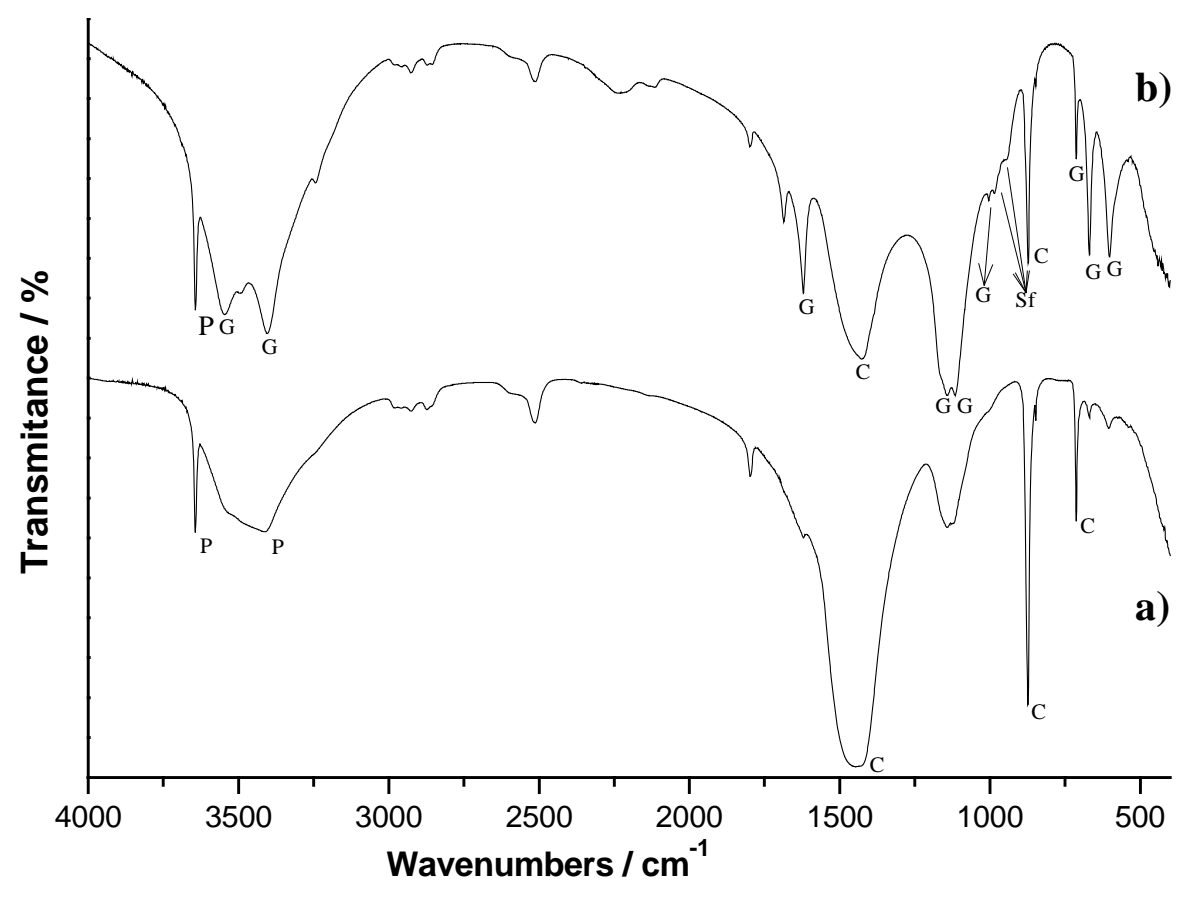

Fig. 6. FTIR spectra of aerial lime-based specimen subjected to a) indoor exposure; b) $\mathrm{SO}_{2}$-chamber exposure. P: Portlandite; C: Calcite; G: Gypsum; Sf: Sulfite.

Hydraulic mortars exposed to outside, indoor and climatic chamber have similar IR spectra. As an example, Fig. 7(a) shows the IR spectrum of a hydraulic sample (28 test days of indoor exposure). Absorption bands at $\sim 1420,874$ and $714 \mathrm{~cm}^{-1}$ reveal the presence of calcite [23]. This spectrum also shows a narrow band at $\sim 3640 \mathrm{~cm}^{-1}$ attributed to the O-H free stretching vibration and a broader band centered at $\sim 3400 \mathrm{~cm}^{-1}$ due to hydroxyl groups [24]. The broad band at 1000-970 $\mathrm{cm}^{-1}$ arises from C-S-H vibrations [7] (Fig. 7(a)). Obviously, this band is missing in aerial lime-based mortars (Fig. 6(a)).

In $\mathrm{SO}_{2}$-chamber exposure (Fig. 7(b)), absorption bands attributed to gypsum are observed, as in the aerial mortars exposed to $\mathrm{SO}_{2}$-rich environment. Additionally bands at 3248, 753 and 643 $\mathrm{cm}^{-1}$ indicate the presence of syngenite. A sharp band at $990 \mathrm{~cm}^{-1}$ and a shoulder at $947 \mathrm{~cm}^{-1}$ give an evidence of sulfite. No calcium hydroxide was detected in the external layer. 


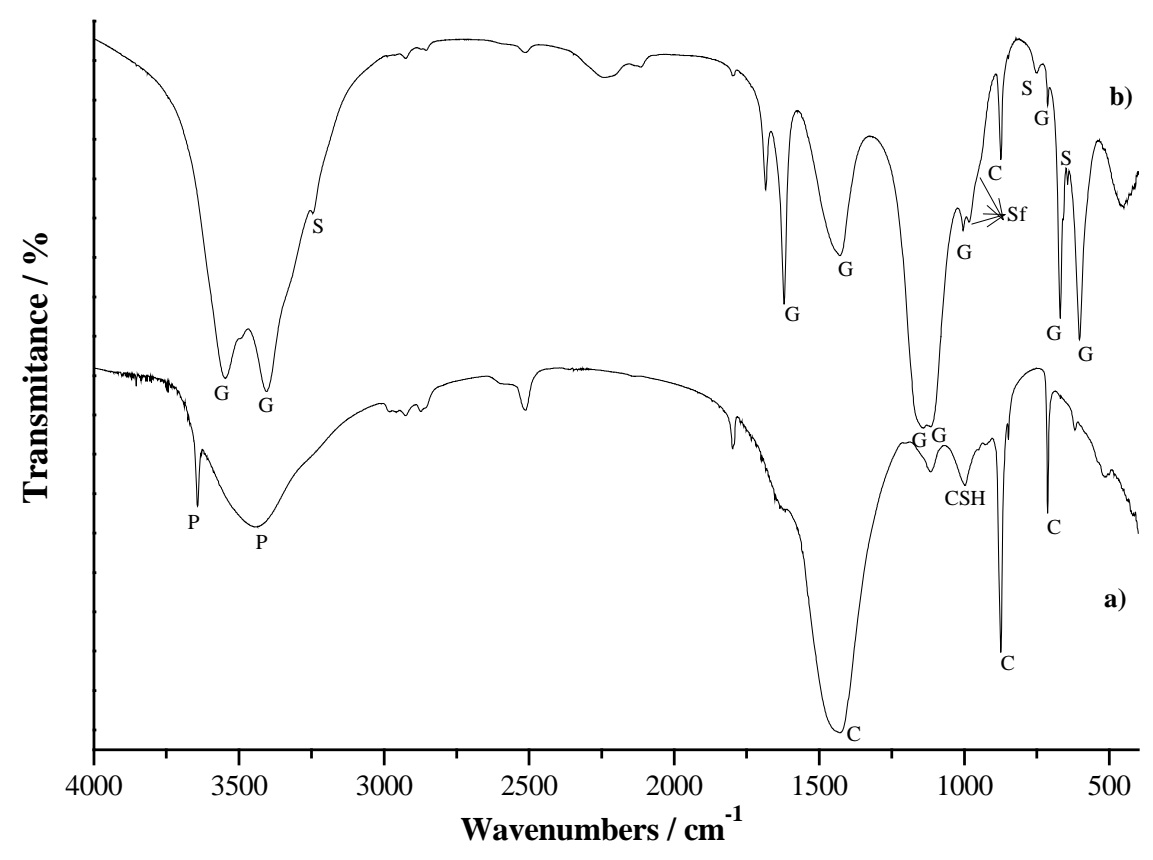

Fig. 7. FTIR spectra of hydraulic lime-based specimen subjected to a) indoor exposure; b) $\mathrm{SO}_{2}$-chamber exposure, external alteration layer. P: Portlandite; C: Calcite; G: Gypsum; S: Syngenite; Sf: Sulfite; C-SH: Calcium silicates hydrated.

\subsection{Thermal studies}

TGA-DTA analyses were performed in order to characterize the mortars. Results are in accordance with the XRD and IR data.

Fig. 8(a) shows TG-DTA curves of the bulk of an aerial mortar exposed 28 days at $\mathrm{SO}_{2}$-rich environment. The endothermic peaks with associated weight losses at $\sim 500^{\circ} \mathrm{C}$ and $\sim 900^{\circ} \mathrm{C}$ are attributed to the $\mathrm{Ca}(\mathrm{OH})_{2}$ dehydroxilation and $\mathrm{CaCO}_{3}$ decarbonation, respectively. Only a very slight endothermic peak at $\sim 160^{\circ} \mathrm{C}$ could prove the existence of a very low amount of gypsum. However, Fig. 8(b) represents TG-DTA curves of the external layer of the same sample. The strong endothermic peak, as a doublet, between $160^{\circ}-180^{\circ} \mathrm{C}$, corresponds to the gypsum dehydration, which takes place in two steps (Eqs. 3 and 4 respectively) [25]:

$$
\begin{array}{cc}
\mathrm{CaSO}_{4} \cdot 2 \mathrm{H}_{2} \mathrm{O} \rightarrow \mathrm{CaSO}_{4} \cdot 1 / 2 \mathrm{H}_{2} \mathrm{O}+3 / 2 \mathrm{H}_{2} \mathrm{O} & \mathrm{T}=162^{\circ} \mathrm{C} \\
\mathrm{CaSO}_{4} \cdot 1 / 2 \mathrm{H}_{2} \mathrm{O} \rightarrow \mathrm{CaSO}_{4}+1 / 2 \mathrm{H}_{2} \mathrm{O} & \mathrm{T}=174^{\circ} \mathrm{C}
\end{array}
$$




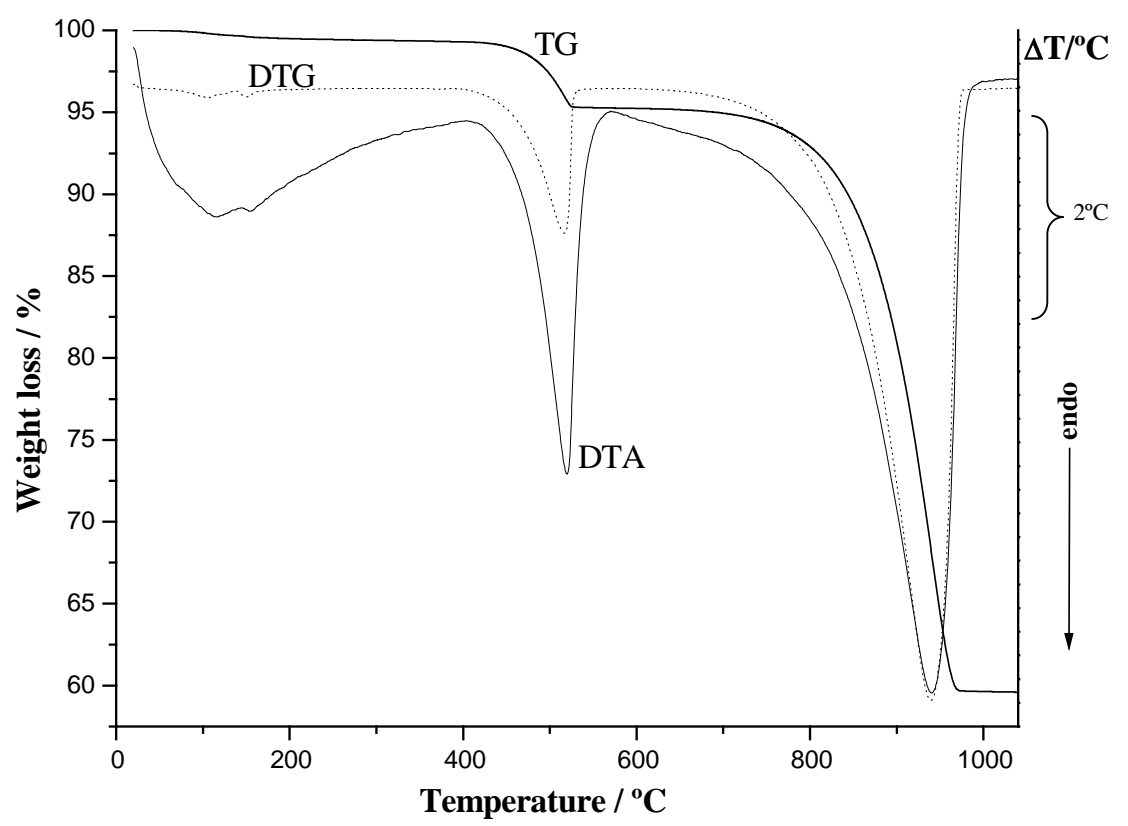

Fig 8(a). TG-DTA curves of the bulk of the sample of an aerial lime-based mortar after 28 test days in $\mathrm{SO}_{2}$-chamber exposure.

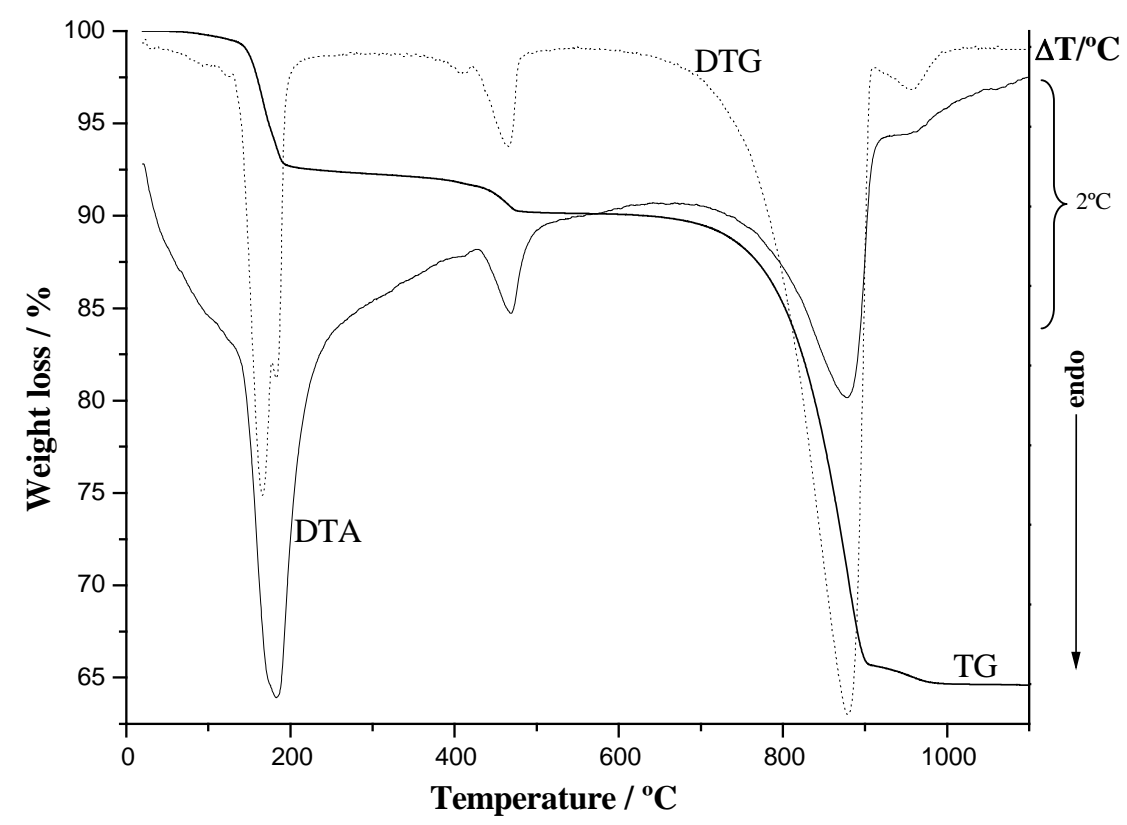

Fig 8(b). TG-DTA curves of the external layer of an aerial lime-based mortar after 28 test days in $\mathrm{SO}_{2}$-chamber exposure

Similar results can be observed for hydraulic mortars. The analysis of the bulk (Fig. 9(a)) shows a dehydration peak at about $150^{\circ} \mathrm{C}$, due to overlapping of C-S-H and ettringite dehydration effects. Fig. 9(b) depicts TG-DTA curves of the mortar surface, showing the strong peak of the gypsum dehydration at $160-180^{\circ} \mathrm{C}$. Endothermic phenomena at 290,400 and 
$550^{\circ} \mathrm{C}$ are attributed to the thermal decomposition of syngenite: dehydration, decomposition and polymorphic transition, respectively [26], meanwhile at $480^{\circ} \mathrm{C}$ the endothermic peak with associated weight loss reveals a small amount of calcium hydroxide.

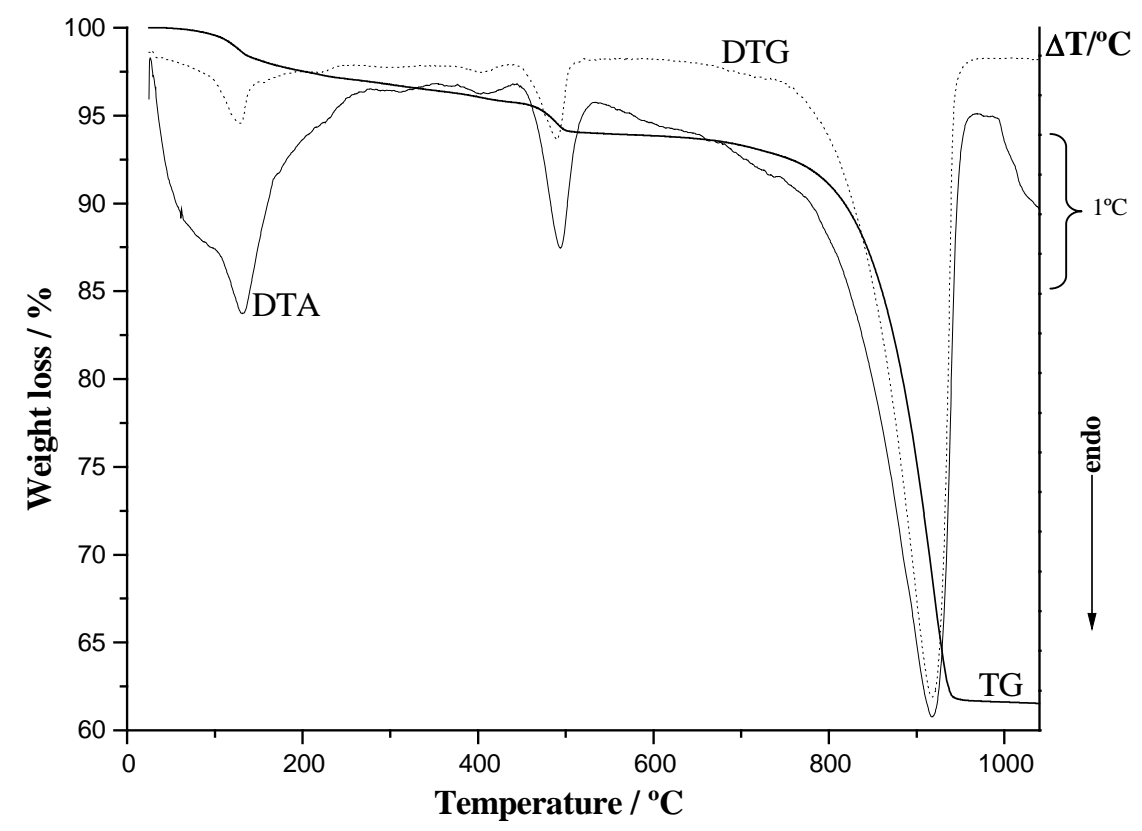

Fig 9(a). TG-DTA curves of the bulk of the sample of a hydraulic lime-based mortar after 28 test days in $\mathrm{SO}_{2}$-chamber exposure

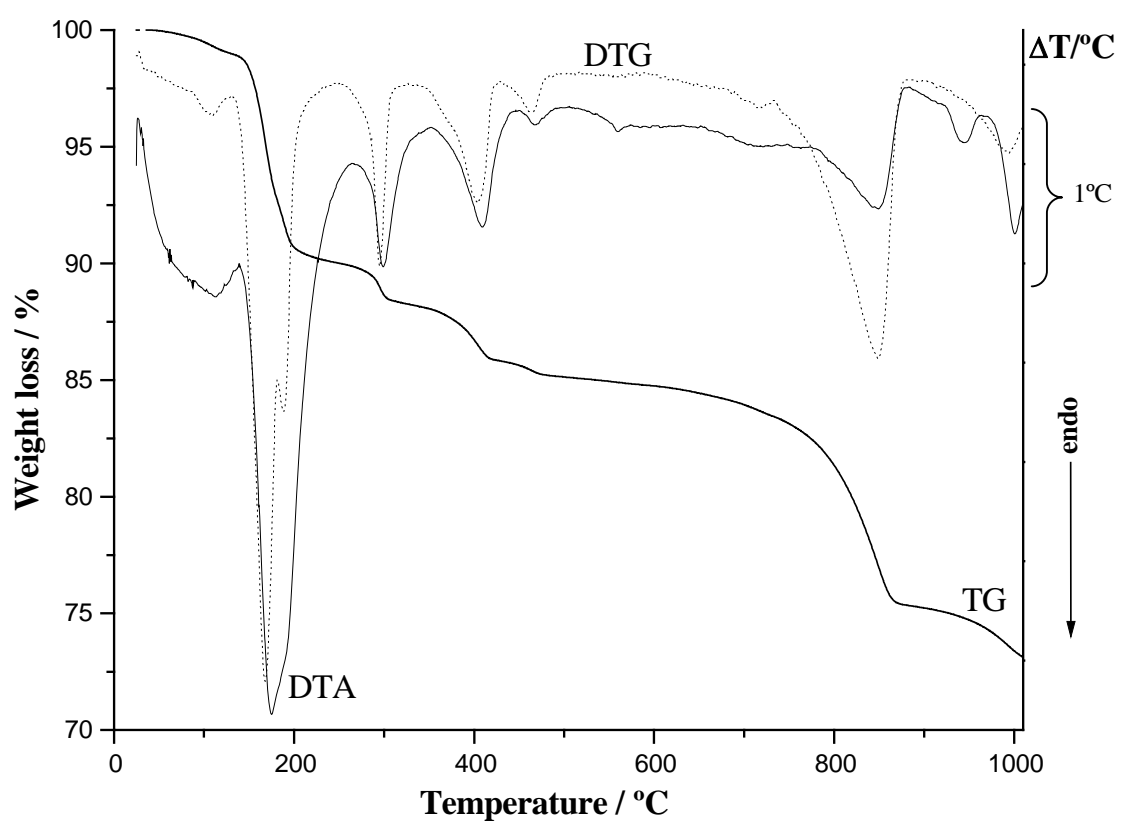

Fig 9(b). TG-DTA curves of the external layer of a hydraulic lime-based mortar after 28 test days in $\mathrm{SO}_{2}$-chamber exposure.

\section{Discussion}


The evaporation of free water from the samples causes a weight decrease, whereas a weight increase will be observed when salts are formed by reactions of the lime with $\mathrm{CO}_{2}$ and $\mathrm{SO}_{2}$ (carbonation and sulfation reactions, respectively) or when the sample reacts with free water to produce hydration products (as C-S-H, ettringite in hydraulic binders). Most of the free water is removed during the curing period, previous to the different exposures, so results do not depend on this phenomenon.

In Fig. 3, aerial lime-based mortars subjected to outside exposure show a weight increase up to 21 days due to carbonation of the calcium hydroxide. The $\mathrm{CO}_{2(\mathrm{~g})}$ reaction is enhanced in the presence of water (optimum at $60 \% \mathrm{RH}$ ) because dissolution of $\mathrm{CO}_{2(\mathrm{~g})}$ is necessary for $\mathrm{CH}$ (calcium hydroxide) carbonation [7,27], which explains the difference between outside and indoor exposures (Tables 5 and 6).

In $\mathrm{SO}_{2}$-chamber exposure, a weight increase takes place due to the $\mathrm{SO}_{2(\mathrm{~g})}$ reaction (sulfate attack process). The presence of bands of calcite and portlandite (FTIR analysis, Fig. 6 b) indicates a certain degree of carbonation. Besides, sulfite appears as an intermediate stage previous to the sulfate formation [28-30]. In weathering exposure (climatic chamber), after 7 test days, the aerial lime mortars do not withstand the climatic cycles, and a total destruction of the specimens is produced.

Hydraulic lime based mortars exhibit an erratic variation of weight in outside exposure strongly influenced by the weather of the test day, which governs the amount of water in the specimens. In indoor exposure, the carbonation degree is low due to the small amount of water (Table 5). The hydration of calcium silicates does not take place in agreement with previous work that stated a C-S-H formation in the first 28 curing days and weight stabilization at the test days of the present work (the process depends on other important parameters come $\mathrm{C}_{2} \mathrm{~S} / \mathrm{C}_{3} \mathrm{~S}$ ratio) [3]. In $\mathrm{SO}_{2}$-chamber exposure, the sulfate attack is responsible for the weight increase. The high $\mathrm{RH}$ in the environment increases the amount of free water (Table 5); the higher amount of free water together the presence of sulfate and the increase in temperature $\left(40^{\circ} \mathrm{C}\right)$ speed up the hydration reaction of calcium silicates to produce C-S-H [31,32]. Different experimental evidences certify this fact: (i) minimum values observed in the $\mathrm{CaCO}_{3} / \mathrm{Ca}(\mathrm{OH})_{2}$ 
ratios at 21 or 28 test days, due to the increment of $\mathrm{Ca}(\mathrm{OH})_{2}$ amount from calcium silicates hydration (Table 6); (ii) the presence of portlandite (Figs. 5(a) and 9(a)). In Fig. 9(b) calcium hydroxide is detected in the external layer, but no in XRD or FTIR measurements, due to the small quantity (around 2.5\%) to be observed by these techniques. It can be established that the low amount of calcium hydroxide on the external layer of the mortar is due to the strong deterioration by sulfate and the great extent of the carbonation.

Syngenite is formed only in hydraulic mortars, as a result of its low solubility ( $2.5 \mathrm{~g} / \mathrm{L})$ at room temperature (Fig. 5(b), 7(b) and 9(b)). The $\mathrm{SO}_{2}$ attack generates potassium sulfate in dry conditions, because it has a high solubility $(120 \mathrm{~g} / \mathrm{L})$. This $\mathrm{K}_{2} \mathrm{SO}_{4}$ is a kinetic product, but it does not appear in wet $\mathrm{SO}_{2}$ attack conditions: syngenite was formed instead of it owing to its lower solubility [7]. It is a thermodynamic control product of the degradation by $\mathrm{SO}_{2}$, as well as gypsum (solubility $2.4 \mathrm{~g} / \mathrm{L}$ ).

In aerial mortars, no syngenite is detected due to the lower amount of potassium in this lime, as checked by chemical analysis (Table 1). Therefore sulfate attack is a surface phenomenon in both aerial lime-based mortars and hydraulic mortars.

In Fig. 5(a), a little amount of ettringite can be generated from the reaction of sulfate, yet present in hydraulic lime (Table 1), with aluminate hidrated during the first curing time of the mortar.

In weathering exposure (climatic chamber), a weight increase is observed due to the higher amount of free water and to the changes of temperature, which promote the hydration of the reactive forms in the mortar. In the specimens tested, no destruction was seen. However, several samples show a high degree of alteration. The position in the climatic chamber has an influence on the alteration degree; samples placed at the center of the chamber showed the highest alteration, since they receive a higher amount of water due to the position of the water sprinklers. Therefore, freeze-thaw cycles produce a considerable alteration degree in these mortars.

\section{Conclusions}


(1) Repair lime-based mortars exposed to outside and $\mathrm{SO}_{2}$-chamber (conditions with high $\mathrm{RH}$ ) showed weight increment, in general, due to the facilitated carbonation enhancing $\mathrm{CO}_{2(\mathrm{~g})}$ dissolution and the sulfate attack in $\mathrm{SO}_{2}$-chamber (aerial and hydraulic specimens), and the promoted calcium silicates hydration (hydraulic mortars).

(2) XRD measurements prove that exposure conditions with a higher RH degree allows a higher carbonation (aerial and hydraulic mortars), and a higher hydration in hydraulic compounds (hydraulic mortars).

(3) By XRD, FTIR and TG-DTA analyses it has been determined the sulfate attack products after $\mathrm{SO}_{2}$-rich environment exposure: aerial specimens give gypsum, whereas hydraulic specimens produce gypsum and syngenite, as thermodynamic control products with a low solubility. Sulfate attack process is a predominantly surface phenomenon.

(4) In order to use lime-based mortars as repairing products, a high RH degree during their application is necessary to carbonate calcium hydroxide and to hydrate hydraulic compounds.

\section{Acknowledgements}

The present study was supported by the Spanish Ministerio de Ciencia y Tecnología, Plan Nacional de Investigación, Desarrollo e Innovación Tecnológica (I+D+I) program, Project MAT 2000-1347.

The authors would like to thank José María Galech (CTH, Navarra), Fernando Moreno (Calinsa S.A., Navarra) and Chaux Bruyeres for the material supplied. We are also grateful to Iñigo X. Garcia-Zubiri for the FTIR observations. 


\section{References}

[1] A. Moropoulou, K. Polikreti, V. Ruf, G. Deodatis, J. Cultural Heritage 4 (2003) 101-108.

[2] J. Lanas, J.I. Alvarez, Cem. Concr. Res. 33 (2003) 1867-1876.

[3] J. Lanas, J.L. Perez Bernal, M.A. Bello, J.I. Alvarez, Cem. Concr. Res. 34 (2004) 21912201.

[4] G. Zappia, C. Sabbioni, C. Riontino, G. Gobbi, O. Favoni, Sci. Total Environ. 224 (1998) 235-244.

[5] S. Martínez-Ramírez, A. Zamarad, G.E. Thompson, B. Moore, Build. Environ. 37 (2002) 933-937.

[6] M.T. Blanco-Valera, J. Aguilera, S. Martínez-Ramírez, F. Puertas, A. Palomo, C. Sabbioni, G. Zappia, C. Riontino, K. Van Balen, E.E. Toumbakari, Cem. Concr. Comp. 25 (2003) 983900.

[7] S. Martínez-Ramirez, Cem. Concr. Res. 29 (1999) 107-111.

[8] C. Sabbioni, G. Zappia, C. Riontino, M.T. Blanco-Valera, J. Aguilera, F. Puertas, K. Van Balen, E.E. Toumbakari, Atmos. Environ. 35 (2001) 539-548.

[9] E.A. Laycock, Constr. Build. Mater. 16 (2002) 195-205.

[10] F. Boutin, P. Bromblet, Weathering of natural stone: causes, mechanism and measurement of stone damage, Proceedings of the 9th International Congress on Deterioration and Conservation of Stone, Venice, 2000, pp. 31-39.

[11] A.J. Klemm, P. Klemm, Build. and Environ. 32 (6) (1997) 509-512.

[12] Y. Shao, C.J. Lynsdale, C.D. Lawrence, J.H. Sharp, Cem. Concr. Res 27 (11) (1997) 17611771.

[13] G. Zappia, C. Sabbioni, M.G. Pauri, G. Gobbi, Mater. Struct. 27 (1994) 469-473.

[14] C. Sabbioni, A. Bonazza, G. Zappia, J. Cultural Heritage 3 (2002) 83-88.

[15] EN 459-1, Building Lime. Part 1: Definition, specification and conformity criteria (2001).

[16] EN 196-2, Methods of testing cement. Part 2: Chemical Analysis of cement (1994).

[17] EN 1015-3, Methods of test mortar masonry. Part 3: Determination of consistence of fresh mortar (by flow table). 
[18] EN 196-1, Methods of testing cement. Part 1: Determination of strength (1995).

[19] EN 1015-11, Methods of test for mortar masonry. Part 11: Determination of flexural and compressive strength of hardened mortar (1999).

[20] UNE-EN ISO 3231. Paints and varnishes. Determination of resistance to humid atmospheres containing sulfur dioxide.

[21] DIN Deutsches Insitut für Normung e.V., DIN 50018, Testing in Alternating Condensation Atmosphere Containing Sulphur Dioxide, May 1988.

[22] C. Ayora, S. Chinchón, A. Aguado, F. Guirado, Spain, Cem. Concr. Res. 28 (9) (1998) 1223-1235.

[23] F. Bosch Reig, J.V. Gimeno Adelanto, M.C.M. Moya Moreno, Talanta 58 (2002) 811-821.

[24] M.J. Blesa, J.L. Miranda, R. Moliner, Vib. Spectrosc. 33 (2003) 31-35.

[25] T. Hatakeyama, Z. Liu, “Handbook of Thermal Analysis”, Wiley, UK, 1998.

[26] L.G. Berg, Salt Minerals, in: R.C. Mackenzie (Ed.), “Differential Thermal Analysis”, Academic Press, New London, 1970.

[27] K. van Balen, D. van Gemert, Mater. Struct. 27(1994) 393-398.

[28] G. Zappia, C. Sabbioni, M.G. Pauri, G. Gobbi, Mater Struct 27 (1994) 469-473.

[29] P. Elfving, I. Panasa and O. Lindqvist, Atmos. Environ. 30 (23) (1996), 4085-4089.

[30] J.L. Pérez Bernal, “Estudio del sistema Dióxido de Azufre-Carbonato Cálcico. Catálisis e inhibición. Protección del Patrimonio Monumental”, Unpublished PhD thesis (in Spanish), Universidad de Sevilla, Sevilla, 2000.

[31] F.M. Lea, “The chemistry of cement and concrete”, Edward Arnold Ltd., Glasgow, 1970. [32] H.F.W. Taylor, “Cement Chemistry”, Academic Press New York, 1990. 